\title{
La hora felipista del siglo XVIII: auge y ocaso de la nación flamenca en el ejército borbónico
}

\author{
Thomas GLESENER \\ Maître de conférences \\ Université Aix-Marseille \\ Maison Méditerranéenne des Sciences de l'Homme \\ CNRS UMR Telemme \\ 13094 Aix-en-Provence, Francia \\ glesener@mmsh.univ-aix.fr
}

Fecha de recepción: 08/09/2011

Fecha de aceptación: 15/12/2011

\section{RESUMEN}

Esta contribución estudia las razones de la persistencia de los privilegios de la nación flamenca en el ejército borbónico durante más de un siglo tras la pérdida de Flandes. Subraya que la renovación por Felipe $\mathrm{V}$ de los derechos de nación es una pieza clave de un proyecto de regeneración de la nobleza española diseñado durante la guerra de Sucesión para favorecer a las familias más adictas a la causa borbónica. Siguiendo el hilo de las reformas que han afectado esos derechos a lo largo del siglo, este trabajo demuestra que los intentos ilustrados de reforma del ejército estamental han sido también tentativas de eliminar la herencia política de Felipe V.

Palabras clave: Ejército, Borbones, nobleza flamenca, Países Bajos, España, Guerra de Sucesión, Felipe $\mathrm{V}$, militares extranjeros.

\section{The Time of King Philip V's Fellows in Eighteenth Century Spain: The Rise and Decline of the Flemish «nation» in the Bourbon Army}

\begin{abstract}
This work studies the reasons of the preservation of the Flemish nation's privileges in the Spanish Bourbon army during more than a hundred years after the dismemberment of the Spanish Monarchy in Europe. This paper underlines that the renewal of the Flemish privileges by king Philip V of Spain was a key factor of the regeneration project of the Spanish nobility during the Spanish War of Succession, in order to favour the most faithful families to the Bourbon party. Focusing on the XVIII ${ }^{\text {th }}$ century's reforms against these privileges, it demonstrates that the enlightened military reformism also tried to tear down the Fillip V's political heritage.
\end{abstract}

Key words: Army, Bourbon Spain, Flemish nobility, Low Countries, Spain, Spanish War of Succession, Philip V of Spain, foreigners. 


\section{INTRODUCCIÓN}

¿Por qué los flamencos tuvieron tanto éxito en la España del siglo XVIII? Al igual que los franceses, irlandeses, vascos y navarros, los flamencos han tenido su "hora", que se puede situar en la primera mitad del siglo XVIII, durante la cual individuos oriundos de las antiguas Diecisiete Provincias consiguieron empleos en la milicia y en la administración política del reino a un nivel inédito ${ }^{1}$. Una de las explicaciones recurrentes a este fenómeno ha sido la particular confianza que los Borbones han acordado a los extranjeros para ocupar puestos claves en la Corte y en los gobiernos provinciales. Por no fiarse de la nobleza española tras la guerra de Sucesión, los Borbones han alentado a extranjeros "antiguos" (franceses, irlandeses y suizos) y "nuevos" (flamencos e italianos) a servir en sus ejércitos en cuerpos de naciones. Confiando en esos nuevos servidores, que no tenían vínculos con la vieja nobleza local, la corona les habría abierto el paso, a través de un perfil de carrera específico, hacia todos los empleos de la alta administración política y militar ${ }^{2}$. Durante el siglo XVIII, hubo voces que empezaron a levantarse contra la presencia extranjera en la cumbre del Estado, y que se fueron fortaleciendo con la paulatina afirmación de un sentimiento nacional. La aparición de una literatura satírica, de pasquines y de panfletos con carácter xenófobo ha sido considerada como la expresión de un movimiento de descontento hacia los ministros extranjeros en particular, y toda la presencia extranjera en general, en los empleos públicos ${ }^{3}$. Finalmente, poco se sabe de la lenta extinción de los cuerpos de naciones, entre fines del siglo XVIII y principios del XIX. La "nacionalización" progresiva del ejército parece haber obligado a las familias extranjeras a irse o a integrarse en la sociedad española ${ }^{4}$.

Esta explicación se basa enteramente en la condición de extranjeros de los flamencos, a pesar de ser una cuestión muy discutible, para entender su presencia en España. Además, no encaja cronológicamente con el caso irlandés, que vive su momento de esplendor a partir del reinado de Carlos III $^{5}$. Tampoco permite entender por qué los vasco-navarros conocen desde principios del siglo una ascensión fulgurante en los

1 Sobre los flamencos en la España del siglo XVIII, nos remitimos a la bibliografía de: GLESENER, Thomas: La garde du roi. Pouvoirs, élites et nations dans la monarchie hispanique (1700-1823), Tésis doctoral inédita, Universidad de Lieja/Universidad de Toulouse, 2007, pp. 612-637.

2 Ozanam, Didier: «Les étrangers dans la haute administration espagnole au XVIIIe siècle», en AmAlRIC, J. P. (ed.), Pouvoirs et société dans l'Espagne moderne, Toulouse, Presses Universitaires du Mirail, 1993, pp. 215-229; Ozanam, Didier: «La restauration de l'État espagnol au début du règne de Philippe V (1700-1724): le problème des hommes», en Bottineau, Y. (dir.): Philippe V d'Espagne et l'Art de son temps, Sceaux, Musée de l'Île-deFrance, 1995, pp. 79-89; AndúJar CASTILlo, Francisco: «Las naciones en el ejército de los Borbones», en GonZÁleZ Cruz, D. (ed.): Extranjeros y enemigos en Iberoamérica: la visión del otro. Del Imperio español a la Guerra de la Independencia, Madrid, Sílex, 2010, pp. 137-154.

EgIDo LóPez, Teófanes: Opinión pública y oposición al poder en la España del siglo XVIII (1713-1759), Valladolid, Universidad de Valladolid, 1971; y varios otros trabajos del mismo autor, entre los cuales: EGIDO LÓPEZ, T.: «La oposición al poder: el desastre de Argel (1775) y la sátira política», en Actas del Congreso internacional sobre «Carlos III y la Ilustración», Madrid, Ministerio de Cultura, vol. 1, 1989, pp. 423-449.

${ }^{4}$ Guillaume, Henri: Histoire des gardes wallonnes au service d'Espagne, Bruselas, 1858; Jansen, André: Les gardes royales wallonnes. Histoire d'un régiment d'élite, Bruselas, Racines, 2003.

${ }^{5}$ Recio Morales, Oscar: Ireland and the Spanish Empire 1600-1825, Dublín, Four Court Press, 2010, pp. 235295. 
sectores financieros del Estado y en las carreras eclesiásticas ${ }^{6}$. ¿Acaso se trata de fenómenos totalmente distintos? Es cierto que cada grupo cultivó su especificidad, reivindicó sus derechos particulares y practicó una endogamia feroz, lo que deja pensar que se trató de casos que caminaban por sendas separadas. Los enfoques comunitarios de varios estudios han acentuado esa impresión, aislando aspectos similares de un mismo proceso. A nuestro parecer, se trató de un amplio fenómeno de renovación de las élites, que concernió tanto a los regnícolas como a los forasteros, que se inició en la alborea del siglo XVIII y que se reprodujo de forma repetitiva a lo largo del siglo, desplazando a algunos grupos para permitir a nuevas familias de anclarse en las estructuras del Estado. El carácter "comunitario" o "nacional" de algunas redes de parentesco y de clientela fue lo de menos: se trató de la manera de cómo, social y políticamente, consiguieron perennizar su posición en las instituciones. Así que, a partir del momento en que se enfoca a las "naciones" no como comunidades de naturales, sino como el resultado de un proceso político de reivindicación de derechos, su estudio permite arrojar luz sobre la manera de cómo se han constituido los grupos de poder en el Estado borbónico.

Siguiendo el hilo del mantenimiento de los privilegios de la nación flamenca en el ejército borbónico, esta contribución pretende superar la cuestión de la "hora flamenca" para entender a través de este caso procesos comunes a las élites del siglo XVIII español. Se trata de comprender quiénes son los individuos que consiguen disfrutar de derechos de nación, por qué los Borbones renuevan esos derechos durante casi cien años tras la pérdida de Flandes, y qué consecuencias esto produce en la sociedad española.

\section{DE LA HORA FLAMENCA A LA HORA FELIPISTA}

Los derechos concedidos a la nación flamenca en España a principios del siglo XVIII no lo fueron por los mismos motivos que en el reinado anterior. Como se sabe, durante los siglos XVI y XVII, los reyes de España habían creado en la Corte instituciones reservadas a los flamencos, o dedicadas a gestionar los asuntos de Flandes (Consejo Supremo de Flandes, la guardia de archeros, el hospital de San Andrés). La función política de tales privilegios consistía, por un lado, en representar en la proximidad del rey la pluralidad territorial de la Monarquía y, por otro, en vertebrar a la Monarquía ofreciendo la posibilidad a los súbditos flamencos de servir en la Corte ${ }^{7}$. A inicios del reinado de Felipe V, esas antiguas instituciones decayeron rápidamente: el Consejo

\footnotetext{
6 CARo Baroja, Julio: La hora navarra del XVIII (personas, familias, negocios e ideas), Pamplona, Diputación foral de Navarra, 1969; GonzÁlez Enciso, Agustín (ed.): Navarros en la monarquía española en el siglo XVIII, Pamplona, EUNSA, 2007; TorRes SÁNChEZ, Rafael (ed.): Volver a "la hora navarra". La contribución navarra a la construcción de la monarquía española en el siglo XVIII, Pamplona, EUNSA, 2010.

7 Martínez Millán, José: «Las naciones en el servicio doméstico de los Austrias españoles (siglo XVI)», en Álvarez-Ossorio Alvariño, A. y García García, B. (dirs.): La Monarquía de las Naciones. Patria, nación y naturaleza en la Monarquía de España, Madrid, Fundación Carlos de Amberes, 2004, pp. 131-161; HorTAL MuÑoz, José Eloy: Los asuntos de Flandes: las relaciones entre las Cortes de la Monarquía Hispánica y de los Países Bajos durante el siglo XVI, Madrid, Editorial Académica Española, 2011.
} 
de Flandes fue suprimido en 1702, la compañía de archeros fue reformada en 1704, y el hospital San Andrés sufrió importantes recortes en $1716^{8}$. Al mismo tiempo, a favor de la reforma de la Casa Real llevada a cabo por Felipe V, aparecieron otras instituciones de índole militar reservadas a los flamencos: el regimiento de la guardia walona (1703) y la compañía flamenca de la guardia de corps (1704) ${ }^{9}$. La creación de estos cuerpos respondió a un patrón político diferente del siglo anterior, dictado por las urgencias del momento: ya no se trataba tanto de integración y de representación política de los territorios en la Corte, sino de fidelizar a los grandes linajes flamencos devotos a la causa borbónica y atraerlos así a España para sostener al joven Felipe V.

¿Por qué Felipe V se fio de la nobleza flamenca? A diferencia de Nápoles, de Castilla o de Aragón, no hubo en Flandes una oposición política de la alta nobleza a la nueva dinastía. Se debió en gran parte a la pérdida de protagonismo político de la nobleza flamenca a lo largo del siglo XVII, pero también al patronazgo ejercido por el rey de Francia sobre las grandes familias de Flandes ${ }^{10}$. En efecto, con las conquistas de Luis XIV en la frontera sur de los Países Bajos, muchas de esas familias pasaron paulatinamente al servicio de Francia, manteniendo a las ramas menores en los territorios bajo dominación española. Fueron los casos de familias prestigiosas como los Croÿ, Montmorency, Isenghien, Melun, Egmont o Bournonville ${ }^{11}$. Por lo tanto, el advenimiento de Felipe V en 1700 abrió perspectivas de paz en la frontera, de integración política y territorial entre España, Flandes y Francia, y alentó por lo tanto a la nobleza a unirse al bando borbónico. No se trató de una adhesión uniforme de toda la oligarquía flamenca, sino de la movilización de contactos y de valedores que cada familia conservaba en Versalles para acercarse a la nueva dinastía. De hecho, esos linajes carecían de unidad y compitieron entre ellos para conseguir las gracias y los favores. La creación de las primeras unidades de "nación flamenca" fue impulsada por los grandes ministros franceses para favorecer a sus hechuras de Flandes. En 1702, la formación de la compañía de mosqueteros fue una iniciativa del marqués de Louville para su protegido, el conde de Ursel. Su reforma, en 1704, y su transformación en compañía flamenca de la guardia de corps, fue un episodio de la lucha de Jean Orry contra Louville, que permitió a una hechura de Orry, el príncipe de T'Serclaes, recibir el mando de la nueva unidad. En 1703, se creó la guardia walona con el fin de otorgarla al duque de Havré, un íntimo de la princesa de los Ursinos ${ }^{12}$.

\footnotetext{
8 García García, Bernardo y Esteban Estríngana, Alicia: «Cambios en las instituciones flamencas en la Corte española: el Consejo Supremo de Flandes, las Guardias Reales y la Real Diputación de San Andrés (1700-1721)», en Álvarez-Ossorio Alvariño, A. y García García, B. (dirs.): La pérdida de Europa. La Guerra de Sucesión por la Monarquía de España, Madrid, Fundación Carlos de Amberes, 2007, pp. 335-378.

9 Glesener, Thomas: «Les "étrangers" du roi. La réforme des gardes royales au début du règne de Philippe V (1701-1705)», Mélanges de la Casa de Velázquez, 35-2 (2005), pp. 219-242.

10 Vermeir, René: «Je t'aime, moi non plus. La nobleza flamenca y España en los siglos XVI-XVII», en YuN Casalilla, B. (ed.): Las redes del imperio. Elites sociales en la articulación de la monarquía hispánica, 1492-1714, Madrid, Marcial Pons, 2009, pp. 313-337.

11 Glesener: op. cit. (nota 1), pp. 50-60; Guignet, Philippe : «Une question mal posée: les Flamands et les Hennuyers se sont-ils ralliés au Roi Très Chrétien (seconde moitié du XVIIe siècle)?», en Agostino, M. y otros (eds.) Les ralliements. Ralliés, traîtres et opportunistes du Moyen Âge à l'époque moderne et contemporaine, Burdeos, Université de Bordeaux III, 1997, pp. 93-110.

12 Glesener: op. cit. (nota 9).
} 
Por lo tanto, Felipe $\mathrm{V}$ no se fió tanto de los flamencos como nación como más bien de los flamencos recomendados por el canal de Versalles. Además, en diciembre de 1700, Felipe V había dejado un poder a Luis XIV para mandar directamente en su nombre en los Países Bajos. Por lo tanto, la "regencia" ejercida por el rey de Francia en Flandes le permitió detectar y recomendar a su nieto a los más fieles de entre todos sus súbditos ${ }^{13}$. Así pues, fue el ejército de Flandes el que se reveló como la gran cantera de oficiales de confianza de los Borbones a principios del siglo XVIII. En efecto, iniciada desde enero de 1701, con una implicación fuerte de la administración militar y hacendística francesa, la leva de un nuevo ejército en Flandes permitió a cantidades de empresarios militares -flamencos, franceses y españoles- de dar muestras de su apego a la nueva dinastía ${ }^{14}$. Fuertemente recomendados por Versalles, esos oficiales venales consiguieron distinguirse en un momento en el que la maquinaria administrativa militar en la Península estaba bloqueada por los Consejos. De este modo, varios oficiales de los tercios españoles de Flandes volvieron a la Península para seguir en sus tierras lo que habían empezado en los Países Bajos: se suele olvidar que Juan de Idiáquez, uno de los héroes de la "hora vasco navarra", procedía del ejército de Flandes y volvió a España en 1703 con las recomendaciones del embajador francés para ocupar la sargentía mayor de la guardia de corps ${ }^{15}$. Igual pasó con otros oficiales españoles procedentes de Flandes, como el andaluz marqués de Villadarias, que tuvo un papel fundamental en la reforma del ejército peninsular, o como el vitoriano Juan Francisco Manrique Arana, quien ocupó cargos militares de primera importancia ${ }^{16}$. Por lo tanto, desde el principio, la creación de nuevas instituciones reservadas a los naturales de Flandes debe ser situada en un contexto más amplio de atracción a la Península de oficiales considerados como los más fieles a la dinastía, no por su procedencia geográfica, sino por la proximidad con los nuevos centros de poder de la dinastía borbónica en Versalles y Bruselas. Así, lo que puede aparecer como el inicio de la "hora flamenca", fue en realidad la hora de los oficiales del ejército de Flandes ${ }^{17}$.

\footnotetext{
13 Pirenne, Henri: Histoire de Belgique, Bruselas, Lamertin, 1926, vol. 5, pp. 87-130.

14 VAN DEN Bogaert, R.: «De organisatie van het Spaans-Zuidnederlandse Leger in dienst van het Anjouaanse regime (1700-1706)», Revue belge d'Histoire militaire, 17-18 (1967), pp. 81-117 y 171-209.

15 Ministerio de Asuntos Exteriores (MAE) (París), Correspondencia Política, Países Bajos, leg. 60, ff. 226227. Sobre Idiáquez, ver: Guerrero ElecAlde, Rafael: «El "Partido vizcaíno" y los representantes del rey en el extranjero. Redes de poder, clientelismo y política exterior durante el reinado de Felipe V», en GuimerÁ RavinA, A. y Peralta Ruiz, V. (eds.): El equilibrio de los imperios: de Utrecht a Trafalgar. Actas de la VIII Reunión Cientifica de la Fundación Española de Historia Moderna: (Madrid, 2-4 de junio de 2004), Madrid, 2005, vol. 2, pp. 85-100; Andújar Castillo, Francisco: «De la periferia a la Corte: la integración de vascos y navarros en los cuerpos de elite del ejército borbónico», en Porres Marijuán, R. y Reguera. Bilbao, I. (eds.): La proyección de la Monarquía hispánica en Europa. Política, guerra y diplomacia entre los siglos XVI y XVIII, Bilbao, Universidad del País Vasco, 2009, pp. 175-196.

16 Glesener, Thomas: "Venalidad y fidelidad en los Países Bajos durante el reinado de Felipe V», en ANDÚJAR Castillo, F. (ed.): Venalidad: procesos, contextos y actores (en prensa). La "hora andaluza" queda aún por estudiar: Gutiérrez NúÑez, Francisco Javier e YbáÑez Worboys, Pilar: «El llamamiento a la nobleza de las "dos Andalucías" de 1706», Revista de historia moderna: Anales de la Universidad de Alicante, 25 (2007), pp. 53-88; ANDÚJAR CASTILlO, Francisco: «Servicios para la guerra, mercedes para las oligarquías. Las recompensas de la guerra de Sucesión en Andalucía», en Bernardo Ares, J. M. (ed.): La sucesión de la monarquía hispánica, 1665-1725, Córdoba, Universidad de Córdoba, 2006, vol. 1, pp. 45-74.

17 GLeSENER: op. cit. (nota 16).
} 
Por razones políticas evidentes, los Borbones se dieron cuenta rápidamente de que no iban a poder conceder privilegios a la nación flamenca en la Corte sin dar las mismas compensaciones a la nación española. Desde 1701 se barajó la posibilidad de crear también en la Casa Real cuerpos militares para españoles con la voluntad de dar aliento a la alta nobleza que se había distinguido hasta entonces por su relativa tibieza hacia el nuevo monarca. Los estrepitosos fracasos de las primeras unidades españolas de la guardia real confiadas al cardenal Portocarrero, al duque de Frías, o al conde de Lemos, sacaron a la luz el fiasco de la política nobiliaria de Luis XIV de domesticación de la alta nobleza a través del servicio militar ${ }^{18}$. A partir de 1705, y de los eventos dramáticos que se produjeron en la Península para los Borbones, desde el asedio a Gibraltar en 1704 hasta la primera evacuación de Madrid de $1706^{19}$, la política de atribución de empleos que había prevalido a la formación de las unidades flamencas se aplicó a las demás: en adelante, debían ser premiados los que dieran pruebas concretas de fidelidad, independientemente de su extracción social. Fue a partir de ese momento cuando algunas familias felipistas españolas, desde las más prestigiosas como los duques de Osuna, hasta la pequeña nobleza provinciana como los "norteños", empezaron a llenar las filas de las nuevas unidades de la guardia real ${ }^{20}$.

El proceso fue idéntico con la formación de la compañía italiana de la guardia de corps en 1703. Durante el viaje a Italia de Felipe V en 1702, la alta nobleza napolitana había querido dar muestras de su apego al nuevo monarca para limpiar la mancha dejada por la conjura de Macchia, el año anterior, en la cual varios nobles se habían implicado. A ese fin, los nobles levantaron a su costa un cuerpo de guardia para custodiar al rey durante su estadía. Sin embargo, durante el viaje del monarca se produjo otra conjura, la del príncipe de Trevisacce, que implicó de nuevo a miembros de la nobleza y a algunos oficiales de la nueva guardia napolitana. De camino de regreso a España, Felipe $\mathrm{V}$ prohibió que la guardia napolitana le acompañase a España y, al año siguiente, cuando se trató de formar la compañía italiana de la guardia de corps, el monarca confió el mando al Duque de Popoli, un noble napolitano miembro del séquito real, ascendido personalmente por Felipe V a Grande de España por haber vencido militarmente a la conjura de Macchia ${ }^{21}$.

Por lo tanto, paulatinamente entre 1703 y 1705, la nueva guardia real se convirtió en el baluarte de las familias de los distintos reinos de la Monarquía que dieron pruebas personales de fidelidad al monarca. Los mandos recayeron en miembros de la media y alta nobleza que no debían su puesto a su sangre y a sus títulos, sino a las pruebas concretas de su lealtad al monarca. Es un proceso que se produjo probablemente en otros ámbitos políticos e institucionales fuera de la milicia, pero es en ésta donde se puede observar de la mejor forma cómo la dinastía llevó a cabo una política de asentamiento y de fortalecimiento de esa nueva elite felipista.

\footnotetext{
18 Rowlands, Guy: «Louis XIV, Aristocratic Power and the Elite Units of the French Armies, 1661 to 1715 », French History, 13 (1999), pp. 303-331.

19 Bernardo Ares, José Manuel: «Las dos Españas de 1706 según las cartas reales de los reyes borbónicos», en Álvarez-Ossorio Alvariño, A. y García García, B. (dirs.): La pérdida de Europa. La Guerra de Sucesión por la Monarquía de España, Madrid, Fundación Carlos de Amberes, 2007, pp. 249-270.

${ }^{20}$ GlesenER: op. cit. (nota 1), pp. 127-131.

${ }^{21}$ Ibidem, pp. 76-77.
} 
Con su nueva Casa Real, Felipe V creó una estructura que debía favorecer a esas familias. Los privilegios concedidos a los oficiales de la guardia real fueron copiados de la Casa Militar francesa y establecidos desde la publicación de las primeras ordenanzas entre 1703 y 1705: un sueldo mayor, un sistema de doble graduación que permitía siempre adelantar a los otros oficiales del ejército, la proximidad al rey, el doble estatus de criado de la Casa Real y de militar, una independencia total de la administración militar con el privilegio de cada jefe militar de tratar directamente con el monarca sobre los asuntos de su cuerpo ${ }^{22}$. Sin embargo, a diferencia de la Casa Militar francesa, Felipe V concedió otras prerrogativas que no constaban en las ordenanzas. Por un lado, se tomó la costumbre de no establecer un trato diferente entre las naciones que componían la guardia real: mientras la guardia suiza debía ceder la precedencia a la guardia francesa, por ser una extranjera y la otra súbdita del rey de Francia, en España, los cuerpos de naciones no estaban jerarquizados por considerar que todas eran equivalentes en méritos ${ }^{23}$. Por otro lado, el rey conservaba el derecho de mantener una vía privilegiada de ascenso en cada compañía de la guardia de corps, dispensando de la regla de la antigüedad a los candidatos mejor recomendados, para que accedieran directamente a los empleos de exentos. Estos eran puestos muy codiciados porque conllevaban el grado de coronel de caballería, a diferencia de Francia donde sólo tenían el grado de teniente coronel. Esto permitió en España a oficiales muy jóvenes de acceder a las coronelías de los regimientos de caballería o a los empleos de la administración político militar ${ }^{24}$. En fin, desde la guerra de Sucesión, era costumbre que los oficiales de la guardia real acumulasen varios empleos, en particular un gobierno o una capitanía general de provincia. Esa práctica, inexistente en Francia, fue limitada al final de la guerra, pero se mantuvo en Cataluña donde, a lo largo de casi todo el siglo, los capitanes generales y los gobernadores de Barcelona fueron al mismo tiempo altos oficiales de la guardia real ${ }^{25}$. Estos tres ejemplos demuestran que Felipe V empleó los cuerpos privilegiados de la Casa Real no como su abuelo - para confirmar y domesticar a la antigua aristocracia-, sino para fortalecer y concentrar los honores en una nueva élite compuesta de un núcleo reducido de familias veteranas de la guerra de Sucesión, entre las cuales se encontraban varios linajes flamencos.

\footnotetext{
${ }^{22}$ AndúJar Castillo, Francisco: «Elites de poder militar: las guardias reales en el siglo XVIII », en CASTELLANO, J.L. y otros (eds.): La pluma, la mitra y la espada. Estudios de historia institucional en la edad moderna, MadridBarcelona, Université de Bordeaux-Marcial Pons, 2000, pp. 65-94.

${ }_{23}$ Archivo General de Simancas (AGS), Guerra Moderna (GM), Supl., leg. 239. Los dos regimientos alternaban en las funciones por no establecer diferencias de rango.

24 Andújar Castillo, Francisco: «Nobleza cortesana: la vía privilegiada de acceso al Generalato en el siglo XVIII», en Rey Castelao, O. y López, R.J. (eds.): El mundo urbano en el siglo de la Ilustración, Santiago de Compostela, Xunta de Galicia, vol. 2, 2009, pp. 489-500.

25 Glesener: op. cit. (nota 1), pp. 306-319; Dedieu, Jean-Pierre: «Los gobernadores de Lérida, Barcelona y Gerona en el siglo XVIII», Pedralbes. Revista d'història moderna, 18-2 (1998), pp. 491-507.
} 


\section{EL PRECIO DE LA FIDELIDAD}

Las pérdidas territoriales que sufrió la Monarquía durante el conflicto sucesorio estrecharon aún más los vínculos entre Felipe V y sus seguidores. Con la derrota de Ramilies (1706), que hizo caer prácticamente la totalidad de los Países Bajos bajo el control de las tropas anglo-holandesas, los flamencos pasaron de ser súbditos sirviendo a sus expensas a su monarca legítimo lejos de sus casas, a exiliados que habían sacrificado su familia y su hacienda a manos de los enemigos para mantenerse fieles en el servicio. Ahora bien, en el contrato moral que el monarca tenía con sus fieles vasallos, cada pulgada de terreno perdido o cada maravedí confiscado en Flandes exigían compensaciones de alguna u otra forma en España. Era un mecanismo que ya se había experimentado en los Países Bajos en el reinado anterior, durante la conquista de las provincias meridionales por las tropas de Luis XIV, y era uno de los fundamentos de la relación política entre el rey y sus súbditos ${ }^{26}$. Así, mientras hubiera la posibilidad de recuperar los Países Bajos, Felipe V seguiría distribuyendo un sinfín de títulos y gracias de Flandes que recaían en los oficiales flamencos a su servicio. En 1710, Simon Reynegom, ayudante de la compañía flamenca de la guardia de corps, obtuvo un título de barón por haber "abandonando su hacienda en poder de los enemigos por no apartarse de la dominación y servicio de Vuestra Majestad su legítimo rey, y señor natural"27. En 1707, Francisco Joseph Bureau, de una familia de regidores de Mons, que tenía dos parientes sirviendo en la guardia walona, obtuvo una confirmación de nobleza por haber "abandonado su hacienda en la confiscación en las últimas guerras para quedar leal y fiel vasallo" 28 . Sin embargo, a veces, las compensaciones ya se hacían en España y no en Flandes: Jean Claude Prudhom, antiguo consejero del Consejo de hacienda de Flandes refugiado en Madrid, que reclamó durante varios años compensaciones por la pérdida de su empleo y de su hacienda, obtuvo al final el corregimiento de Guadix ${ }^{29}$. Esa política de compensaciones, y por lo tanto de fidelización de los exiliados, no concirnió solamente a los flamencos o a los demás súbditos de los territorios periféricos. Los catalanes, los valencianos y los aragoneses, tras el desembarco del archiduque en Barcelona, o incluso los castellanos, tras las dos evacuaciones de Madrid, también conocieron la experiencia del exilio y tenían la posibilidad de hacer valer el sacrificio de sus casas para demostrar su fidelidad absoluta a Felipe $\mathrm{V}^{30}$.

\footnotetext{
26 Ruiz Ibañez, José Javier: Felipe II y Cambrai: el consenso del pueblo. La soberanía entre la práctica y la teoría política (1595-1677), Madrid, 1999; Esteban Estríngana, Alicia: «El consenso como fundamento de la cohesión monárquica. La operatividad política del binomio protección-defensa en los Países Bajos del siglo XVII», en Guillamón Alvárez, F.J. y Ruiz Ibañez, J.J. (eds.): Lo conflictivo y lo consensual en Castilla. Sociedad y poder político (1521-1715). Homenaje a Francisco Tomás y Valiente, Murcia, Universidad de Murcia, 2001, pp. 325-376.

27 Archivo Histórico Nacional (AHN), Estado (E), leg. 1491-3.

${ }_{28}$ AHN, E, leg. 1491-3.

29 AHN, E, leg. 1491-1; AGS, GM, leg. 2233

30 GimÉnEz LóPEZ, Enrique: «El exilio de los borbónicos valencianos», Revista de historia moderna: Anales de la Universidad de Alicante, 25 (2007), pp. 11-52; AndúJAR CASTILlo, Francisco: «Nobleza catalana al servicio de Felipe V: la compañía de granaderos reales», Pedralbes. Revista d'historia moderna, 27 (2007), pp. 292-314. Sobre la construcción de la lealtad en Castilla: MuÑoz Rodríguez, Julio David y Guillamón Álvarez, Francisco Javier: «La lealtad castellana en la Guerra de Sucesión: movilización social y representación del poder en una sociedad en guerra», Revista de historia moderna: Anales de la Universidad de Alicante, 24 (2006), pp. 513-536.
} 
Por lo tanto, a medida que sus dominios se estrechaban, Felipe V debió de distribuir cada vez más compensaciones a los felipistas de toda la Monarquía que le siguieron en el exilio, obligándole a buscar nuevos expedientes para cumplir con su deber moral. Se conoce bien la política represiva de confiscaciones de los Borbones hacia los austracistas, pero raramente se ha puesto de relieve que se enmarcaba en una política de compensaciones para las familias que habían perdido su hacienda por su fidelidad a Felipe $\mathrm{V}^{31}$. En efecto, durante la guerra, se barajó la posibilidad de entregar los bienes confiscados de los austracistas a las familias felipistas exiliadas. Como bien decía el confesor del rey, Robinet, en una consulta al Consejo de Estado, confiscar los bienes de la nobleza antigua para entregárselos a los fieles servidores era legítimo, y permitiría "establecer una segura nobleza". Según el padre confesor, si algunos se ofendieran de ver tantas familias extranjeras premiadas, "quedaran sin motivo cuando vean que ya son todos vasallos de España y que han de vivir en ella y que vean tanta nobleza con asiento en España" ${ }^{32}$. Melchor Macanaz, que apoyó también la idea de "regenerar la nobleza", recuerda que siempre los reyes habían atraído a su servicio a la gente de más valor, e incluso subrayaba que "toda la nobleza de Castilla hace gran vanidad de ser su origen de Francia y otros reinos extraños". Por lo tanto, Felipe V solo tenía que renovar el ciclo, permitiendo a nuevas familias nobles de radicarse en España ${ }^{33}$. Hoy se sabe que los bienes confiscados fueron mucho menos de lo previsto, y que al final se irían devolviendo a los herederos de los austracistas ${ }^{34}$. Sin embargo, el principio de la compensación de las pérdidas sufridas por los fieles servidores se mantuvo como un eje central de la política nobiliaria borbónica: en vez de dar bienes confiscados, fueron los títulos, hábitos y pensiones los que sirvieron de compensación.

Sin embargo, la corona debía enfrentarse con las resistencias puestas por los Consejos de Castilla y las instituciones del reino. De hecho, desde finales de la Edad Media, los reinos de España habían creado las reservas de empleos para los naturales, lo que hacía difícil recompensar a los flamencos sobre los bienes del reino ${ }^{35}$. La edad de oro, durante la guerra de Sucesión, en la cual Felipe V otorgó títulos de nobleza en Flandes para sus oficiales flamencos que le servían en España, no duró más allá de la separación definitiva del territorio en 1713. Solamente las grandes familias flamencas consiguieron obtener títulos de Castilla, como las Grandezas para los jefes de la guardia real, o alguna gracia personal como el título de duque concedido a la familia Bournonville en 1717 o el derecho de fundar un mayorazgo de Castilla en $1738^{36}$. Para los demás, la concesión de títulos nobiliarios siguió, pero resultó más

31 Kamen, Henry: The War of Succession in Spain, 1700-1715, Bloomington, Indiana University Press, 1969, pp. 309-360; León SAnz, M. Virginia y SÁnchez Belén, Juan A.: «Confiscación de bienes y represión borbónica en la Corona de Castilla a comienzos del siglo XVIII», Cuadernos de Historia Moderna, 21 (1998), pp. 127-175.

32 AHN, E, leg. 2973.

33 Ibidem.

34 León SAnz, M. Virginia: Entre Austrias y Borbones. El Archiduque Carlos y la monarquía de España (17001714), Madrid, Sigilo, 1993

35 Pérez Collados, José María: Una aproximación histórica al concepto jurídico de nacionalidad. La integración del Reino de Aragón en la monarquía hispánica, Zaragoza, Institución Fernando el Católico, 1993.

${ }^{36}$ AHN, Consejos, leg. 2753, f. 20; Archivos Generales del Reino (AGR) (Bruselas), Familias y particulares (FP), Ursel, L. 328. 
complicada: se dieron casos muy raros de títulos de Castilla concedidos a oficiales flamencos de la pequeña nobleza, como el de vizconde de Roussel (1740), el conde de Gages (1745) o el de barón de Mayals (1754) otorgados respectivamente a Carlos Roussel, Juan Dumont Gages y Francisco Bassecourt, los tres oficiales de la guardia walona ${ }^{37}$. Para el resto, tras la pérdida de Flandes, la desigualdad de trato entre los flamencos se acentuó entre los que tenían los apoyos suficientes en la Corte-que les permitían conseguir las gracias y mercedes tradicionalmente reservadas a los súbditos de los reinos de España-, y los que carecían de relaciones. Sin embargo, mercedes como los beneficios eclesiásticos eran difíciles de obtener para todos, tanto para la alta como para la pequeña nobleza flamenca. En efecto, suponían la concesión previa de una carta de naturaleza que, aunque sea dada por decreto real, debía de ser sometida a la aprobación de las ciudades castellanas con voto en las Cortes ${ }^{38}$. Es la razón por la cual esas gracias fueron muy raras y reservadas a pocos individuos muy bien recomendados en la Corte. En 1712, Eugenio de Croix, natural de Lille, teniente de la compañía flamenca de la guardia de corps, y uno de los militares más destacados de la guerra de Sucesión, obtuvo una carta de naturaleza para gozar de una pensión sobre el arzobispado de Toledo ${ }^{39}$. En 1729, Jorge Prospero Verboom, natural de Bruselas, ingeniero general, obtuvo cartas de naturaleza para sus hijos, lo que permitió a uno de ellos conseguir un canonicato de la catedral de Zaragoza ${ }^{40}$. En cada caso, esas mercedes suscitaron arduos debates en los ayuntamientos entre los partidarios de la atribución exclusiva de esas gracias a los naturales del reino, y los que entendían que el rey debía de "remunerar los servicios de los muchos extranjeros que se han esmerado en el real servicio de Vuestra Majestad con ocasión de la constitución pasada de las muchas guerras que ha tenido esta corona" ${ }^{41}$. En todo caso, suponían un grado excepcional de proximidad con el rey, que no todos los flamencos poseían, para que el monarca aceptase iniciar un proceso largo e incierto de negociación con las ciudades del reino. Por lo tanto, para evitar el enfrentamiento, Felipe V recurrió con prioridad a las gracias que relevaban del realengo o sobre las cuales las reticencias que se podían presentar eran desdeñables. Así, no es de extrañar que los hábitos de las órdenes militares y sus encomiendas se hayan convertido en la fuente principal de gracias para los militares extranjeros. Durante el siglo XVIII, 54 militares naturales de Flandes fueron agraciados con un hábito, de los cuales se podría añadir unos 50 más si consideramos los descendientes de la segunda generación nacidos en España con apellido francés o neerlandés ${ }^{42}$. Durante la misma época, fueron 91 los irlandeses que consiguieron

37 AHN, Consejos, leg. 8977; AHN, Consejos, leg. 8978, AHN, Consejos, leg. 764. La mayoría de los títulos llevados por los oficiales flamencos eran títulos de sus regiones de origen y no eran títulos de Castilla.

${ }^{38}$ Herzog, Tamar: Defining Nations. Immigrants and Citizens in Early Modern Spain and Spanish America, New Haven-Londres, Yale University Press, 2003, pp. 64-93; Hermann, Christian: «Naturales y forasteros: Les exclusives d'accès aux bénéfices de l'Eglise dans l'Espagne moderne», en Les sociétés fermées dans le Monde ibérique (XVIeXVIIIe siècles). Définitions et problématique, Paris, CNRS, 1986, pp. 189-201.

39 Cremades Griñan, Carmen María: «Cartas de naturaleza: Concepto, privilegios y repercusión en el estado eclesiástico», Cuadernos de Investigación histórica. Seminario “Cisneros", 9 (1986), p. 56; AGR, FP, Croix, leg. 9.

${ }^{40}$ Archivo Histórico de la Villa de Madrid (AHVM), Secretaría, 2-348-25; Archivo Histórico de Protocolos de Barcelona, Rondo, Test. 1741-1755, f. 31-39.

${ }^{41}$ AHVM, Secretaría, 2-394-63, Diputación de Madrid a Felipe V, 28 de septiembre de 1715.

42 Glesener, Thomas: «Poder y sociabilidad: las élites flamencas en España a través de los expedientes de las 
también llevar la cruz de una de las cuatro órdenes españolas ${ }^{43}$. De hecho, el Consejo de Órdenes no tenía prácticamente ninguna capacidad de oposición a las decisiones reales. Para los irlandeses, llegó el caso que el Consejo presentara quejas al rey sobre la dificultad de averiguar la autenticidad de las pruebas de nobleza ${ }^{44}$. Sin embargo, en la práctica, y al menos para los candidatos flamencos, la organización de las encuestas dejó un margen de maniobra muy amplio a los pretendientes para que las pruebas fueran aprobadas sin ninguna dificultad ${ }^{45}$.

Desde mucho antes del final de la guerra, los conflictos con las instituciones del reino eran previsibles, así que la corona se preparó para asumir la carga de mantener a las familias felipistas. Por haberse distinguido en la milicia, fueron las gracias militares las más fáciles de otorgar. Entre 1701 y 1706, se nombraron en el ejército de Flandes nada menos que 8 tenientes generales, 10 mariscales de campo y 33 brigadieres $^{46}$. Sin embargo, con la llegada de los exiliados a España, las necesidades en gracias militares aumentó y las posibilidades no eran infinitas. En 1714, se decretó la prohibición de acumular dos empleos militares, por motivo de la

reuni[ón] en España de casi todas las tropas que Su Majestad tenía en Flandes, Milán, Nápoles y Sicilia (...) que servían y se mantenían en diferentes partes de la monarquía a costa de aquellas provincias, y recargando hoy todo este gasto y peso sobre el limitado caudal de la real hacienda en España, en cuyo continente tampoco puede haber bastantes empleos para ocupar decentemente a todos los que por la reducción de la monarquía han quedado desacomodados (...) [Su Majestad] se halla en el embarazo y sentimiento de no tener empleos correspondientes para consolar y acomodar decorosamente a los muchos cabos principales que han quedado sin ejercicio ${ }^{47}$.

Por lo tanto, la particularidad de España al final de la guerra de Sucesión fue que se encontró con una oficialidad extremadamente cosmopolita que disfrutaba de un capital político elevado por los servicios prestados durante la guerra. Para asentar en la Península y retribuir con gracias militares a esas familias de exiliados existían dos opciones: o conservar los privilegios de nación en la milicia para mantener reservas de empleos o, al contrario, hacer de todos los empleos militares un espacio profesional abierto, sin distinciones de naciones, en el cual todos los oficiales pudieran

órdenes militares (siglo XVIII)», en Crespo Solana, A. y Herrero SáncheZ, M. (coords.): España y las 17 provincias de los Países Bajos. Una revisión historiográfica (XVI-XVIII), Córdoba, Universidad de Córdoba-Fundación Carlos de Amberes, 2002, pp. 169-188. Entre 1700 y 1724, dos tercios de los hábitos fueron concedidos a militares: Giménez CARrillo, Domingo Marcos: «Los militares y las órdenes militares castellanas durante el reinado de Felipe V», en García Hurtado, M.R. (ed.): Soldados de la Ilustración. El ejército español en el siglo XVIII, La Coruña, Universidade da Coruña, 2012, pp. 230-237.

43 Recio Morales, Óscar, «El lastre del apellido irlandés en la España del XVIII», en Salinero, G. y Testón NuÑEz, I. (eds.): Un juego de engaños: movilidad, nombres y apellidos en los siglos XV a XVIII, Madrid, Casa de Velázquez, p. 114.

44 Biblioteca del Palacio Real, II-2832, ff. 291-300. El Consejo de Órdenes a Felipe V (1727); Recio Morales, Oscar: "“Una nación inclinada al ruido de las armas”. La presencia irlandesa en los ejércitos españoles, 1580-1818: ¿la historia de un éxito?», Tiempos modernos: Revista Electrónica de Historia moderna, 10 (2004), http://www. tiemposmodernos.org/ [Consulta: 11 de julio 2011].

45 GLesener: op. cit. (nota 42).

${ }^{46}$ AHN, E, leg. 1415.

47 AGS, GM, leg. 2241. 
solicitar empleos sin ninguna discriminación por razones de su origen. Se trataba en realidad de dos concepciones distintas del ejército - uno compuesto de cuerpos privilegiados (las naciones) y el otro regido por reglas universales- que estructuraron la organización y los conflictos políticos en torno a la milicia a lo largo del siglo XVIII. Eran una vertiente, característica de la situación española, de un debate más amplio que atravesaba toda la Europa ilustrada de la época entre los defensores de un ejército estamental y los reformadores, que apelan por la creación de un ejército nacional ${ }^{48}$. Los Borbones no zanjaron el debate: el ámbito militar español se quedó, durante gran parte del siglo XVIII, como un espacio profesional abierto al componente extranjero, con focos privilegiados en torno a los cuerpos de naciones.

\section{PRIVILEGIO DE NACIÓN Y OLIGARQUIZACIÓN DEL EJÉRCITO}

Al salir de la guerra, la conservación de los cuerpos de la nación flamenca parecía la forma más obvia de ayudar a los oficiales flamencos para asentarse en España. En 1710, la llegada a España de los restos de 26 regimientos del ejército de Flandes para compensar la defección francesa demostraba la voluntad de recrear en la Península el ejército de naciones ${ }^{49}$. Para toda la oficialidad flamenca, los regimientos de nación eran el peldaño imprescindible para instalarse en la Península, empezar la carrera y traer parientes. Además, el mando de esas unidades constituía prebendas indispensables para que los grandes linajes flamencos puedan seguir el servicio con decencia. Sin embargo, a pesar del reconocimiento de los servicios prestados, los privilegios de la nación flamenca fueron duramente atacados al final de la guerra. Paradójicamente, no fue la pérdida de Flandes lo que debilitó la posición de los flamencos, sino la ruptura de los vínculos entre Francia y España. Como se ha dicho, los grandes linajes que habían conseguido la formación de las unidades flamencas por su proximidad con el entorno francés de Felipe V salieron muy debilitados tras la muerte de Luis XIV y de la reina María Luisa. El coronel de la guardia walona, el Duque de Havre, no sobrevivió a la derrota del partido francés: en 1716, él y varios de sus parientes fueron expulsados de España ${ }^{50}$. En un periodo muy confuso, en el cual se produjo una amplia redistribución de los equilibrios de poder en las cortes española y francesa, las reformas militares del cardenal Alberoni, con el pretexto de reducir el gasto militar, denotaron una voluntad de reorganizar los grupos de poder en la corte madrileña. Se trató así de disminuir el poder y la presencia en palacio de la élite militar cosmopolita constituida durante la guerra de Sucesión, y formada mayoritariamente por familias españolas y flamencas próximas al partido francés, con el objetivo de que no puedan rivalizar con los nuevos grupos de poder llegados desde Italia con la reina Isabel

48 Cepeda Gómez, José: «Servir al Rey y servir a la Nación. Ilustrados, liberales y el deber militar», Cuadernos de Historia Moderna, 16 (1995), pp. 139-156; Sмітн, Jay M.: The Culture of Merit. Nobility, Royal Service and the Making of Absolute Monarchy in France, 1600-1789, Ann Arbor, Michigan University Press, 1996; BlaufarB, Rafe: The French Army 1750-1820. Carrers, Talent, Merit, Manchester-New York, Manchester University Press, 2002.

${ }^{49}$ AGR, Consejo Real de Felipe V, leg. 548.

50 Guillaume: op. cit. (nota 4), pp. 77-106; AGS, GM, leg. 2255. 
Farnesio $^{51}$. Por lo tanto, entre 1715 y 1720, toda la élite militar sufrió recortes, y las unidades flamencas fueron las más afectadas. En 1715, la gran reforma de la infantería redujo los regimientos flamencos de 26 a $9^{52}$. El año siguiente, la reforma llegó directamente al corazón de la élite militar al disminuir los efectivos de la guardia real en casi un 75\%: la compañía flamenca de la guardia de corps quedó suprimida, y con ella la importantísima vía privilegiada para el acceso al generalato. Tras la salida de España del Duque de Havré, el regimiento de la guardia walona pasó de 3.800 a 750 hombres ${ }^{53}$, mientras que, al mismo tiempo, la Cámara de Castilla iniciaba una visita del hospital San Andrés de los Flamencos para recortar sus privilegios ${ }^{54}$.

El mantenimiento de las unidades flamencas se debió a la habilidad política de algunos miembros de la nobleza flamenca. Tras la pérdida de Flandes, los que se mantuvieron al servicio de España fueron linajes menores, generalmente los jefes de las ramas flamencas de las grandes familias que pasaron al servicio de Francia: así ocurrió con Guillaume de Melun, marqués de Risbourg (Richebourg), cabeza de la rama flamenca de los príncipes de Epinoy, pasados al servicio de Luis XIV en la segunda mitad del siglo XVII. También fue el caso de Michel Joseph de Bournonville, segundón de los marqueses de Sars en el Hainaut español, mientras que la rama mayor -los príncipes de Bournonville- vivían en Versalles y servían en los ejércitos franceses ${ }^{55}$. Sus servicios durante la guerra de Sucesión les confirieron títulos y gracias que no podían esperar quedándose o regresando a sus regiones de origen. A pesar de los riesgos de confiscación, la posición adquirida en España era mucho más interesante que volver a Flandes y quedarse apartados del favor imperial por su fidelidad a Felipe V. Son ellos los que consiguieron adaptarse al nuevo rumbo político en Madrid y colocarse bajo la protección de la reina Isabel Farnesio y de los altos nobles italianos de su entorno ${ }^{56}$. Así, en 1719, el marqués de Risbourg obtuvo el restablecimiento de los efectivos de la guardia walona y, en 1720, el duque de Bournonville el de la compañía flamenca de la guardia de corps ${ }^{57}$.

A pesar de ser muy diferentes, esas dos unidades eran la clave para garantizar a los oficiales flamencos y a sus familias mantenerse en la cúpula militar. Por un lado, el regimiento de la guardia walona era un mastodonte del ejército, con 4.200 hombres que ofrecía 170 empleos de oficiales, y que gestionaba de manera autónoma sus propios caudales, que se elevaron desde los 4.739 .294 reales en 1715 hasta los 6.484.117 en $1790^{58}$. Además, como se ha dicho, el coronel, como director e inspector de su

\footnotetext{
51 Saint-Simon, Louis de Rouvroy (duque de) : Mémoires (1691-1721), ed. Y. Coirault, Paris, Gallimard, vol. 8 , 1988, pp. 103-104.

52 Gómez Ruiz, Manuel y Alonso Juanola, Vicente: El ejército de los Borbones, Madrid, Servicio Histórico Militar, vol. 1, 1989, pp. 36-44.

53 AGS, GM, leg. 2255; Portugués, José Antonio: Colección general de las ordenanzas militares, Madrid, Antonio Marin, vol. 5, 1764, pp. 64-70.

54 Vidal Galache, Florentina y Vidal Galache, Benicia: Historia del Hospital de San Andrés de los Flamencos 1594-1994, Madrid, Fundación Carlos de Amberes, 1996, pp. 65-74.

55 Ursel, Baudouin de: «La Maison de Bournonville», Le Parchemin, 51-244 (1986), pp. 210-265.

56 SAInT-Simon: op. cit. (nota 51), vol. 8, pp. 338-341.

57 Portugués: op. cit. (nota 53), vol. 5, pp. 81-83.

58 AGS, GM, leg. 2255; AGS, Dirección General del Tesoro, Inv. 33, leg. 36. En comparación, un regimiento de línea costaba a la hacienda real un promedio de 950.000 reales.
} 
cuerpo, tenía la prerrogativa exclusiva de presentar personalmente al rey los candidatos a los empleos de oficiales. No tenía ninguna influencia sobre las carreras, regidas por el principio de la antigüedad, pero sí de conseguir empleos a los segundones de un sinfín de familias que venían a aumentar sus redes de clientes ${ }^{59}$. Por lo tanto, fue en esa unidad que se constituyeron las dinastías de oficiales (Bassecourt, Croix, Glimes, Flodorp, etc.) varios de los cuales, gracias a la doble graduación, accedieron a decenas a los gobiernos provinciales ${ }^{60}$. Por otro lado, la compañía flamenca de la guardia de corps no ofrecía tales cantidades de empleos, puesto que sólo contaba con 200 hombres y apenas 20 plazas de oficiales, pero tenía en su seno la vía privilegiada de acceso al generalato. Aunque el capitán no tenía el poder de dispensar la regla de la antigüedad y de elegir directamente a los exentos, tenía una capacidad de influencia sobre la decisión regia ${ }^{61}$. Esa influencia hizo del capitán de guardia de corps una persona con mucho poder: a través de su recomendación, los jóvenes oficiales flamencos podían esperar a acceder directamente al grado de coronel y, desde éste, pretender la coronelía de un regimiento de línea, un gobierno provincial o un empleo en la Corte. En todo caso, el mantenimiento del privilegio de nación en la guardia real permitió a las familias felipistas flamencas prosperar en España, y en particular las grandes familias, que eran las que controlaban los empleos de mando. Allí, los oficiales tenían una fuente estable de ingresos, una gran proximidad al rey y un ascensor social que les permitía estar sobre representados en el generalato, a pesar de sus pocos efectivos a escala del ejército ${ }^{62}$.

Sin embargo, esta situación privilegiada sólo se podía mantener mientras que el rey siguiese confiriendo esos empleos a los veteranos de la guerra de Sucesión, a sus parientes y descendientes. Si algunas familias fueron paulatinamente a integrarse localmente y a diversificar sus fuentes de ingreso, la mayoría de los oficiales de los cuerpos flamencos siguieron muy dependientes del sueldo de sus empleos para poder mantenerse en España ${ }^{63}$. Ahora bien, por su condición privilegiada, los cargos de oficiales de la guardia real eran muy codiciados por varios pretendientes, y el rey mismo estuvo tentado de usar esos empleos para recompensar a nuevos favoritos. Por lo tanto, para los oficiales flamencos, el mayor riesgo venía de un ejercicio descontrolado de la gracia real que condujese al rey a nombrar directamente en sus cuerpos, pasando por encima de los jefes. De hecho, en varias ocasiones, el rey se sirvió de los empleos en las unidades flamencas de su guardia real para complacer a algún hijo de la nobleza titulada española, o también para atraer a su servicio a segundones de la nobleza europea. Así, en 1719, el conde de Grosberg, un pariente del Elector de Baviera, fue nombrado directamente por el rey en la guardia walona. A petición del

\footnotetext{
59 Glesener, Thomas: «Les frontières de la nation. L'identité corporative d'un régiment étranger dans l'armée espagnole (XVIIIe siècle)», en Bertrand, M. y Planas, N. (dirs.): Les sociétés de frontière. De la Méditerranée à l'Atlantique (XVI'-XVII siècle), Madrid, Casa de Velázquez, 2011, pp. 243-257.

${ }^{60}$ De los 356 capitanes de la guardia walona en el siglo XVIII, 64 (18\%) ocuparon gobiernos provinciales. Según Guillaume: op. cit. (nota 9), pp. 265-432 y la base de datos Fichoz (CNRS).

${ }^{61}$ GlesENER: op. cit. (nota 1), pp. 233-248.

62 Por ejemplo, la oficialidad de los cuerpos flamencos de la guardia real no forman más del $4 \%$ de todos los oficiales del ejército, pero representan el $12,3 \%$ de todos los brigadieres de infantería y caballería. Según: Fichoz (CNRS). Ver a este propósito: ANDÚJAR CASTILlo: op. cit. (nota 22).

${ }^{63}$ Glesener: op. cit. (nota 1), pp. 257-261.
} 
ministro plenipotenciario de Baviera en la Corte, ascendió sistemáticamente en el cuerpo con dispensa de antigüedad ${ }^{64}$. En 1752, mientras el capitán de la guardia de corps presentó los dos oficiales más antiguos de su compañía a dos plazas de exentos vacante, el rey nombró por decreto a Álvaro Navia, hijo del marqués de Santa Cruz, y a Joaquín Ponce, marqués del Prado ${ }^{65}$. En efecto, los exentos de la guardia de corps, por su íntima proximidad con los miembros de la familia real, eran de lejos las plazas más codiciadas, y obligaban al capitán a negociar cada vacante para que los empleos recayesen en las filas de los oficiales procedentes de las familias felipistas de Flandes. De un centenar de exentos nombrados por la vía privilegiada de la compañía flamenca en el siglo XVIII, se puede evaluar aproximadamente en solamente 25 los candidatos recomendados por el capitán ${ }^{66}$. Por lo tanto, para las familias felipistas de Flandes, lo que estaba en juego era el control de los empleos en sus propios cuerpos de nación. Había que garantizar que las estructuras creadas y los privilegios concedidos por la fidelidad prestada durante el conflicto sucesorio no fuesen aprovechados por otros.

Una primera respuesta fue la patrimonialización de los empleos de mando. La familia de Bournonville fue la que tuvo más éxito en su estrategia de control de las instituciones flamencas, llegando a transmitirse en tres ocasiones, de 1720 a 1784 , el empleo de capitán de la guardia de corps ${ }^{67}$. Pretendiendo encarnizar los intereses de la nación flamenca en España, los Bournonville convencieron paulatinamente a la corona de que las dispensas en la compañía flamenca debían de ser atribuidas a flamencos, y transformar así la vía privilegiada en una "vía flamenca". Era una manera de resistir a los potentes candidatos que solicitaban empleo directamente al rey, y de utilizar esa influencia para desarrollar clientelas entre los oficiales flamencos más ambiciosos. Como decía el marqués de Croix en 1746, a propósito del duque de Bournonville: "ese cuerpo, entre sus manos, es un recurso considerable para la gente del país a la cual puede hacer placer y darle grandes servicios sin poner mucho de su parte" ${ }^{68}$. Una segunda respuesta a la inseguridad profesional fue el corporativismo. Por el tamaño de su regimiento y su mayor alejamiento de la Corte, los oficiales de la guardia walona desarrollaban una fuerte identidad profesional que les hacía reacios a toda intervención exterior en los asuntos de su cuerpo. El mismo coronel no podía imponer su voluntad a sus hombres: en 1715, el duque de Havré denunciaba las pretensiones del "gremio" de los capitanes que quería "forma[r] una república por cuya pluralidad de votos, quedasen expóticos (sic) y el coronel ejecutor de sus voluntades" 69 . Se debía en gran parte al hecho de que los oficiales se "auto recluten" exclusivamente a través de sus redes sociales, sometiendo a sus candidatos - parientes y amigos- al coronel para que les presentase al rey. Ese sistema no produjo documentación puesto que pasa exclusivamente por el conocimiento y la recomendación mútua sin ningún intermediario administrativo. De hecho, no se conserva ninguna prueba de nobleza escrita previa a la admisión en las guardias walonas. El simple

\footnotetext{
64 AGS, GM, leg. 2240.

${ }^{65}$ AGS, GM, leg. 2269.

${ }^{66}$ AGS, GM, legs. 2224-2226, 2241-2286 y 5914-5924.

${ }^{67}$ Andújar Castillo, Francisco: «La corte y los militares en el siglo XVIII», Estudis, 27 (2001), pp. 91-120.

68 AGR, FP, Croix, leg. 10.

${ }^{69}$ AGS, GM, leg. 2243.
} 
hecho de ser familiar de un oficial del cuerpo, y de ser presentado por el coronel al rey, suponía que los candidatos tenían las cualidades necesarias para servir. Por lo tanto, ese sistema permitía, al coronel, tener siempre a disposición una cantera de candidatos entre los cuales poder elegir a su gusto, y a los oficiales, tener una gran facilidad en conseguir empleos para sus parientes ${ }^{70}$.

En ambos casos, la defensa de los privilegios y la vigilancia sobre la atribución de los empleos se hacían en nombre de la memoria del vasallaje, de los servicios prestados por la "nación" flamenca durante la guerra de Sucesión, y de los méritos contraídos en el servicio de los Borbones de ambos lados de los Pirineos. Así, Bournonville, en varias ocasiones, apoyó sus peticiones manifestando a Felipe $\mathrm{V}$ el "tan justo derecho al dominio de los Países Bajos, y tan directa sucesión de la casa de Borgoña", recordando que su protección permitía de "avivar y permanecer el amor a Vuestra Majestad y a esta monarquía de aquellos vasallos [de Flandes]"71. No dejaba de recordar "el celo y el amor de los flamencos para Sus Majestades", que habían sacrificado toda su hacienda desde la guerra de Sucesión por la ocupación de sus tierras por los enemigos de la Monarquía ${ }^{72}$. Igual pasaba con los oficiales de la guardia walona cuando se intentaba recortar el más mínimo de sus privilegios, exigiendo que:

Se dignará Su Majestad considerar que los Valones son vasallos suyos como los Españoles, y no tropas extranjeras ni auxiliares, por cuya razón dejaron parientes y haciendas para seguir y servir en sus reales ejércitos sin haber nunca conocido otro soberano $^{73}$.

Así pues, tanto la memoria del vasallaje, de la fidelidad dinástica, como la memoria de los sacrificios de la guerra de Sucesión, siguieron justificando, varios años después de la pérdida de Flandes y del final de la contienda, el mantenimiento de los derechos colectivos de la "nación flamenca" y un trato equivalente entre los cuerpos flamencos y españoles. La transmisión del empleo de capitán de la compañía flamenca en la misma familia, en tres ocasiones, durante casi 65 años, demuestra que son argumentos que tenían una efectividad concreta y justificaban la continuación de los privilegios de nación. De esa forma, los oficiales flamencos, por el empeño que pusieron en defender los privilegios de sus unidades, contribuyeron a la oligarquización de la milicia. Con el paso del tiempo, los derechos de nación, del mismo modo que el fuero de la guardia real, se convirtieron en una pieza clave del carácter estamental del ejército español dieciochesco.

\footnotetext{
70 Glesener: op. cit. (nota 59), pp. 245-247.

71 AHN, E, leg. 3488: Bournonville a Felipe V [1720].

72 AGS, GM, leg. 2258: Bournonville a José Patiño, Madrid, 20 de febrero de 1736.

73 AGS, GM, Supl., leg. 239: Lannoy a Miguel Durán, Madrid, 01 de enero de 1720.
} 


\section{REFORMAR EL EJÉRCITO DE NACIONES}

Que no hallo razón de que varios cuerpos del ejército finjan nombres in partibus, como Belgia, Batavia, Ultonia, pues ha dado Dios tantas vastas provincias de que pueden tomar honrados nombres sus regimientos, llamándose Valencia, y Murcia y no Limerick y Frisia $^{74}$.

Esta citación famosa del marqués de la Mina, el gran inspirador de la reforma militar del marqués de la Ensenada de 1749, subraya los acentos patrióticos que acompañaban el reformismo ilustrado español. Interpretado por los mismos contemporáneos como una reacción contra los extranjeros ${ }^{75}$, el discurso patriótico justifica en realidad de una amplia empresa de reforma del ejército estamental y de los diversos privilegios que lo componen: fuero de la Casa Real, vía privilegiada, derechos de nación. La reforma militar de 1749 concretaba varias críticas que ya se habían formulado en años anteriores contra la organización del ejército español heredada de la guerra de Sucesión. En 1730, Francisco de Moya, un ferviente defensor de las milicias provinciales, fue uno de los primeros en sugerir que cada unidad de la guardia real estuviera ligada a una provincia de España, con plazas reservadas para los milicianos más beneméritos $^{76}$. En esencia, Moya formuló las grandes claves del reformismo ilustrado concerniente a los cuerpos privilegiados: no se trataba de suprimirlos, sino de atribuir las plazas al mérito. Este proyecto fue retomado en sus grandes líneas por el marqués de la Ensenada, desde que accedió a la Secretaría de Guerra en 1743, y aún más tras la muerte de Felipe V. El marqués de la Mina, una hechura de Ensenada, denunciaba hacia 1747 la hipertrofia de las tropas de la Casa Real que, con apenas 9.000 hombres, contaban con 3 capitanes generales, 10 tenientes generales, 10 mariscales de campo, 36 brigadieres y un centenar de coroneles ${ }^{77}$. El objetivo de la reforma, según él, era hacer del ejército una gran herramienta de movilización del reino, y de transformar los cuerpos privilegiados en premio para los soldados beneméritos ${ }^{78}$. En efecto, la reforma militar de 1749 iba a ser probablemente el ataque más duro contra los cuerpos privilegiados. Además de la reducción de efectivos en el número de guardias y cadetes (de 900 a 402), las medidas más importantes concernieron al sometimiento de la guardia de corps al control de la Secretaría de Guerra, la reducción del número de exentos de 24 a 18 por compañía y, sobre todo, la disminución del grado asociado al empleo de exento de coronel al de teniente coronel ${ }^{79}$. Por técnica que pueda parecer, la reforma de Ensenada se focalizó en la columna vertebral de los privilegios conce-

\footnotetext{
74 Guzmán Dávalos, Jaime (marqués de la Mina): Máximas para la guerra, Tolosa, Pedro Robert, [1767], p. 392.

75 Argenson, René-Louis de Voyer (marqués de): Mémoires et journal inédit du marquis d'Argenson, ministre des Affaires étrangères sous Louis XV, París, P. Jannet, vol. 3, 1857, p. 124.

76 Moya Torres y Velasco, Francisco: Manifiesto Universal de los males envejecidos que España padece [1730], ed. A. Domínguez Ortiz, Madrid, 1992, pp. 454-456.

77 AGS, GM, leg. 2267, Mina a Ensenada (hacia 1747).

78 AGS, GM, leg. 2265, Mina a Ensenada, Mentón, 21 de junio de 1747.

79 AndúJar CASTILlo, Francisco: «La reforma militar del marqués de la Ensenada», en Guimerá Ravina, A. y Peralta Ruiz, V. (coords.): El equilibrio de los imperios: de Utrecht a Trafalgar. Actas de la VIII Reunión Cientifica de la Fundación Española de Historia Moderna (Madrid, 2-4 de Junio de 2004), Madrid, Fundación Española de Historia Moderna, 2005, pp. 519-536.
} 
didos a las familias felipistas a inicios del siglo XVIII. La reducción del número de exentos y su limitación al grado de teniente coronel ya no les permitía las mismas salidas hacia los mandos de regimientos, los empleos de la Casa Real o los gobiernos territoriales. Además, la enfeudación de los capitanes de la guardia de corps al secretario de Guerra acababa con el derecho de tratar de boca con el rey de los asuntos de sus cuerpos ${ }^{80}$. La reforma de Ensenada intentó luchar así contra la oligarquización de la cúpula militar, atacándose a los mecanismos que permitían a unas familias ocupar la cumbre de la jerarquía militar.

De hecho, la reforma prolongaba una política llevada desde el ministerio de José Patiño de frenar el monopolio de los grandes linajes felipistas sobre los empleos de mando de la guardia real. En 1733, la viuda del duque de Osuna no consiguió que su hijo sucediera a su padre en el mando del regimiento de guardias españolas ${ }^{81}$. Entre 1733 y 1741, la coronelía del regimiento quedó vacante, al igual que en las guardias walonas, donde la coronelía quedó sin titular durante 12 años tras la muerte del marqués de Risbourg en $1734^{82}$. Entre 1743 y 1747, el marqués de Ensenada consiguió paulatinamente colocar hechuras suyas en los principales empleos de la guardia de corps. En 1743, el ministro apoyó los nombramientos del duque de Huéscar a la compañía española, del príncipe de Masserano a la compañía italiana y, en 1744, del marqués de Bondadreal a la ayudantía genera1 ${ }^{83}$. La compañía flamenca era la única unidad que se mantuvo bajo el control de un veterano de la guerra de Sucesión, el viejo duque de Bournonville. En 1746, tras varias tentativas de eliminación, Michel Joseph de Bournonville aprovechó la embajada extraordinaria de su primo francés, el mariscal de Noailles, para obtener la futura de su empleo para su sobrino. Esta embajada, considerada por los contemporáneos como un gran momento de celebración de los vínculos dinásticos en el crepúsculo del reinado de Felipe V, estuvo cargada de mucho simbolismo ${ }^{84}$. De hecho, el duque de Bournonville era perfectamente consciente de que, en el contexto de la próxima llegada al trono de Fernando VI, la futura sonaba como la continuación de la herencia felipista. Por eso, durante el funeral de Felipe V, celebrado pocas semanas después, delante de toda la Corte reunida frente al despojo del primer Borbón, el duque de Bournonville fingió un aturdimiento y cedió el bastón de mando de su compañía a su sobrino ${ }^{85}$.

Como se sabe, la caída del marqués de Ensenada provocó inmediatamente un restablecimiento de los cuerpos privilegiados en todas sus prerrogativas ${ }^{86}$. Pero lo que la reforma de Ensenada no había conseguido, el desarrollo conjunto de la monarquía administrativa y del clientelismo real lo iba a hacer durante el reinado de Carlos III. Dos elementos entraron en cuenta para explicar el debilitamiento de los privilegios de nación en la década de 1780. Primeramente, los secretarios de Guerra se involucraron

80 AndúJar CASTillo: op. cit. (nota 79), pp. 530-534.

81 AGS, GM, leg. 2230.

82 LuYnes, Charles-Philippe d'Albert (duque de): Mémoires du duc de Luynes sur la cour de Louis XV (17351758), ed. L. Dussieux y E. Soulié, Paris, Firmin Didot, vol. 2, 1860, p. 165.

${ }^{83}$ AGS, GM, leg. 2137.

84 LuYNES: op. cit. (nota 82), vol. 7, pp. 330-331; ArgENSON: op. cit. (nota 75), vol. 3, p. 64.

${ }^{85}$ MAE, Memorias y Documentos, España, leg. 155, ff. 243-246: Bournonville a Noailles (18 de julio de 1746).

${ }^{86}$ AndúJar Castillo: op. cit. (nota 79), pp. 535-536. 
cada vez más en los asuntos de la guardia real: sin tomar medidas espectaculares, las prerrogativas de los jefes de cuerpo sufrieron pequeños recortes. En la guardia de corps, el poder de los capitanes quedó cada vez más supeditado a la influencia creciente del sargento mayor, que colaboraba con las oficinas de la Secretaría. En 1769 y 1786, se publicaron nuevos reglamentos que estrechaban cada vez más la autonomía de los capitanes de guardias ${ }^{87}$. Ese proceso lento culminó entre 1792 y 1795 , cuando Carlos IV, colocando a Godoy en la sargentía mayor, lo proclamó jefe del cuerpo delante de los capitanes ${ }^{88}$. En la guardia walona, el mismo proceso reglamentario se produjo con la publicación de una nueva ordenanza en $1773^{89}$. Sin embargo, la implicación de la corona se manifestó de forma más profunda a raíz del incremento del precio de la recluta. Las intervenciones repetidas de la hacienda real para ayudar a los oficiales a reclutar en Flandes e Italia, permitió una mayor injerencia en la gestión interna del cuerpo y en sus cuentas ${ }^{90}$. Por lo tanto, en aproximadamente veinte años, la amplia autonomía concedida a los jefes de las tropas reales disminuyó lentamente, cediendo cada vez un poco más de terreno al control político de la Secretaría.

El segundo elemento fue el auge del clientelismo real, que provocó una demanda creciente de los súbditos para servir en la inmediación del rey ${ }^{11}$. Eso incitó, por un lado, a Carlos III a recuperar el monopolio sobre las vías privilegiadas de las tres compañías de la guardia de corps. Empezando por la italiana, en la cual el antiguo rey de las Dos Sicilias colocó a varios de sus antiguos súbditos, el rey recurrió después a las otras dos compañías para distribuir las gracias. La influencia de los capitanes sobre los nombramientos disminuyó drásticamente, debiéndose limitar a aceptar en sus unidades a los candidatos nombrados por orden del rey ${ }^{92}$. En el caso de los flamencos, ese proceso privó completamente a la familia Bournonville de la fuente de su poder sobre la oficialidad flamenca. Obligó a esta última a buscar directamente el favor real en vez de pasar por la protección del capitán de la compañía flamenca, llevando así a una disolución de la vida comunitaria ${ }^{93}$. En los regimientos de la guardia, a partir de finales de los años 1780, las solicitaciones para conseguir empleos de oficial se acumularon en la mesa del secretario de Guerra. En 1790, en el regimiento de guardias españolas, además de los 84 cadetes reglamentarios, había 85 supernumerarios, y 100 el año siguiente, obligando al coronel a pedir que se suspendiese la

87 AGS, GM, leg. 2284: Método y reglas que ha resuelto el rey observe el Real Cuerpo de Guardias de Corps en el detall del servicio (27 de noviembre de 1786); Gómez Ruiz y Alonso Juanola: op. cit. (nota 52), vol. 2, pp. $235-243$.

88 GLESENER, Thomas: «Godoy y la guardia real: reforma y oposición nobiliaria (1784-1808)», en JIMÉNEZ Estrella, A. y Andújar Castillo, F. (dirs.): Los nervios de la guerra: estudios sociales sobre el ejército de la Monarquía Hispánica (ss. XVI-XVIII), Granada, Editorial Comares, 2007, pp. 317-346.

89 Ordenanzas de S.M. para el regimen, govierno, servicio, y disciplina de los Regimientos de Guardias de Infantería Española, y Walona,..., Madrid, Pedro Marin, 1774.

90 AGS, GM, leg. 2332: Noticia de los reparos más sustanciales que se han encontrado en las cuentas generadas del regimiento de reales guardias walonas... (Madrid, 16 de mayo de 1778); GLESENER, Thomas: «La estatalización del reclutamiento de soldados extranjeros en el siglo XVIII», en GARCía HurTAdo: op. cit. (nota 42), pp. 239-263.

91 Sobre el clientelismo real a través los empleos militares ver EsdaILE, Charles: The Spanish army in the Peninsular War, Manchester, 1988, pp. 20-21; ANDÚJAR CASTILlo, Francisco: «Nepotismo, clientelismo y fidelidad. De Floridablanca a Godoy (1789-1798)», Cuadernos de Historia Moderna. Anejos, VII (2008), pp. 179-211.

92 Glesener: op. cit. (nota 1), pp. 382-390.

93 Ibidem, pp. 390-395. 
admisión de nuevos candidatos ${ }^{94}$. Mientras tanto, el regimiento de guardias walonas, que ha mantenido un reclutamiento más endogámico, ni siquiera llegaba a completar las plazas vacantes del número. Por lo tanto, en muy poco tiempo, frente al atoramiento en el cuerpo español, los candidatos solicitaron plazas en el walón pidiendo al secretario que se les dispense del cuarto flamenco que no poseían. Frente a las decenas de solicitaciones, el secretario tomó la costumbre de dispensar y de nombrar directamente a los empleos, sin pasar por la aprobación del coronel, creando así una crisis sin precedente en el seno de la oficialidad ${ }^{95}$. En dos años, la composición social de los jóvenes oficiales había cambiado totalmente: "Casi todos los cadetes que hay en el regimiento son ya españoles que ignoran el idioma francés", deplora el coronel en 1791, estimando que a esa juventud "el móvil que les inspira es únicamente el de sus ascensos, que juzgan más fáciles [en este regimiento] que en ningún otro, y no la afición a la carrera militar" ${ }^{\prime \prime}$. En unos pocos meses, la endogamia profesional celosamente preservada por el cuerpo se desmoronó. A partir de ese momento, la oficialidad perdió todo control sobre el reclutamiento de sus miembros, las cadenas migratorias procedentes de Flandes se agotaron, y el cuerpo se españolizó rápidamente.

A estos factores hay que añadir otros dos de carácter coyuntural, pero que refuerzan los procesos que ya se han descrito. Por una parte, las crisis de los cuerpos flamencos coincidieron con la extinción biológica de los últimos descendientes de los grandes linajes flamencos felipistas. En 1784, Wolfgang de Bournonville, sobrino de Michel Joseph, murió sin descendencia directa, dejando vacante el cargo de capitán de la compañía flamenca, sin que hayase ninguna familia flamenca de importancia en Madrid que pudiese pretenderlo. La candidatura del primer teniente de la compañía, Bruno Lalaing Calasanz, conde de Lalaing, natural de Badajoz, de padre flamenco y de madre aragonesa, no tenía ni el prestigio ni los apoyos suficientes para conseguir el cargo. El rey nombró al príncipe de Masserano, de apenas 24 años de edad y cabeza de una de las dinastías saboyanas más potentes en Madrid, otorgando así por primera vez la compañía flamenca a alguien sin ningún vínculo con Flandes ${ }^{97}$. En 1791, se produjo prácticamente lo mismo en las guardias walonas: con la muerte de Teodoro de Croix, antiguo virrey del Perú y recién nombrado coronel, se extinguió otro viejo linaje felipista. En cambio, el rey nombró a Pablo Sangro Mérode, príncipe de Castelfranco, jefe de una casa de la alta nobleza napolitana, natural de Nápoles pero de madre flamenca. En la crisis que atravesaba el cuerpo, el caballero de Croix había intentado resistir a los nombramientos masivos hechos por la Secretaría, recordando a Carlos IV la "soberana intención del señor rey D. Felipe Quinto, su augusto abuelo" de reservar el cuerpo a los flamencos ${ }^{98}$. Por su lado, el príncipe de Castelfranco ofreció poca resistencia, reivindicando "otro modo de pensar de los coroneles y directores del cuerpo mis antecesores", y permitiendo así la rápida españolización de la oficialidad ${ }^{99}$. Entre ambos, las memorias familiares no eran las mismas, por no deber

\footnotetext{
${ }_{94}$ AGS, GM, leg. 5935

95 AGS, GM, leg. 5949.

96 AGS, GM, leg. 5950.

97 AGS, GM, leg. 2283.

98 AGS, GM, leg. 5950

99 AGS, GM, leg. 5950.
} 
el príncipe de Castelfranco su posición social a los servicios prestados por sus parientes en la contienda sucesoria. Por lo tanto, con la extinción biológica de los grandes linajes felipistas, fueron también una memoria colectiva y una identidad profesional las que se debilitaron.

El segundo elemento coyuntural fue el estallido de la Revolución francesa y su posterior extensión a los Países Bajos. La ruptura de la alianza con Francia desestabilizó completamente las redes económicas y las rutas de comunicación que se habían establecido en el espacio dinástico, y que permitían traer a los reclutas desde la partida de Lieja ${ }^{100}$. En 1792, la invasión de Lieja por las tropas republicanas obligó a los reclutadores españoles a abandonar completamente el norte de Europa y a centrarse en sus antiguos focos de reclutamiento de Génova y Parma. El abandono de la partida de Lieja, que abastecía a las guardias walonas -pero también a toda la infantería extranjera-, obligó a contraer los efectivos. En 1792 los tres últimos regimientos de línea flamencos fueron reformados ${ }^{101}$. En 1800 faltaban a los tres regimientos irlandeses de Irlanda, Hibernia y Ultonia 1.979 hombres y sólo se abastecían por la recluta que llegaba desde Parma ${ }^{102}$. La guardia walona se mantenía en pie sólo gracias al aporte de soldados españoles, hasta que la reforma de 1803 redujo sus efectivos de 1.000 hombres ${ }^{103}$. Sin embargo, el debilitamiento de los regimientos de naciones no significaba que la corona renunciase a hacer llegar hombres y reclutas desde el extranjero, sino que recurría en adelante a los cantones suizos, que se comprometieron en sus capitulaciones a asegurar ellos mismos la recluta ${ }^{104}$.

En resumen, se puede situar la desaparición de hecho de los derechos de la nación flamenca en el tránsito de finales de los años 1780 a principios de los años 1790 . No fueron víctimas de una gran reforma, como la que intentó el marqués de la Ensenada, sino que sufrieron de una serie de factores convergentes: el control mayor de la administración militar, el auge del clientelismo real, la extinción biológica de los linajes felipistas y el desmoronamiento de las redes de abastecimiento de reclutas por el estallido de la Revolución francesa. En teoría, las últimas unidades flamencas desaparecieron a principios del siglo XIX: en 1807, la nueva ordenanza de la guardia de corps abandonó las denominaciones nacionales, y en 1818, los regimientos de la guardia exterior cambiaron sus nombres por números ${ }^{105}$. En la práctica, hacía ya veinte años que esas unidades habían dejado de ser de naciones, por haber perdido completamente su carácter endogámico. En 1808 Napoleón ya había aconsejado a su hermano "suprimir el nombre de guardia walona, que hoy es un nombre deshonrado y ridículo" 106 .

100 AGS, GM, leg. 5949.

101 Gulllaume, Henri: Histoire de l'infanterie wallonne sous la maison d'Espagne (1500-1800), Bruselas, Imprimerie Hayez, 1876, p. 194.

102 AGS, GM, leg. 5955.

103 Gómez Ruiz y Alonso Juanola: op. cit. (nota 52), vol. 4, pp. 236-266 y 307-311.

104 GLESENER: op. cit. (nota 90).

105 Gómez Ruiz y Alonso Juanola: op. cit. (nota 52), vol. 5, t. 2, pp. 353-354.

106 Correspondance de Napoléon Ier, Paris, Imprimerie Nationale, vol. 18, 1865, p. 114. 


\section{5. ¿HACIA UN EJÉRCITO NACIONAL?}

El ocaso de la nación flamenca en el ejército español no se explica por el auge de un sentimiento anti extranjero en España, sino por la voluntad, o de destruir, o de controlar un residuo particularmente endogámico heredado de los privilegios concedidos por Felipe $\mathrm{V}$ a sus seguidores durante el conflicto sucesorio. En el reinado de Fernando VI, el "casticismo" o "nacionismo" de los ensenadistas fue una herramienta política destinada antes que todo a golpear en el núcleo duro de la élite militar, el más reacio a todo cambio ${ }^{107}$. Por lo tanto, a ojos de los ensenadistas, el militar extranjero se había ido confundiendo con la figura del militar cortesano. Eso se debió en gran parte al carácter fuertemente endogámico de las unidades extranjeras: mientras que en las unidades españolas la competición por los empleos fue muy alta, en los cuerpos de nación los empleos se distribuían entre un número muy reducido de familias ${ }^{108}$. Por lo tanto, existió el sentimiento de que los extranjeros fueron los que más se habían aprovechado de los privilegios concedidos por Felipe $\mathrm{V}$ a raíz de la contienda sucesoria. Se estableció así un vínculo inseparable entre los privilegios de la oligarquía militar y los privilegios de nación, el conjunto formando el "sistema" creado por Felipe $\mathrm{V}$ y con el cual los ensenadistas quisieron acabar. Así, el reformismo ilustrado, a pesar de sus acentos patrióticos, nunca puso en duda el derecho de los extranjeros a servir en el ejército en el mismo pié que los demás y a ser atendidos por el rey por sus méritos. En efecto, el pensamiento meritocrático característico de la Ilustración defendía una concepción del servicio real como un espacio de emulación de todas las personas que deseaban sacrificar su vida por el monarca. En ello no importaba ni el origen social ni el geográfico, sino sólo los méritos personales ${ }^{109}$. "No hay más nación que el bueno y el malo", escribía el marqués de la Mina, que repetía que "el buen extranjero es por derecho de hospitalidad acreedor a las piedades del príncipe, en igualdad con el nacional, como tenga mérito" ${ }^{110}$. Sin embargo, el empeño que los ensenadistas pusieron en desprestigiar y destruir los derechos de nación, intentando borrar así una de las mayores huellas del felipismo en las instituciones militares, llevó a crear confusión en los objetivos políticos. Aunque el marqués de la Mina nunca se opuso directamente al servicio de los extranjeros, debía constatar que era así que se interpretaba su acción:

Jamás he sido contrario de que se atienda el extranjero bueno, pero me ha dolido siempre mucho la preferencia que estamos dando 46 años ha, con perjuicio y despecho de los nuestros, a un tumulto de inútiles, que nos desfrutan y nos desprecian. Y el caso es que esta distinción tan justa, me la tergiversan y dicen que los aborrezco ${ }^{111}$.

\footnotetext{
107 Sobre el "nacionismo", ver: Fernández Albaladejo, Pablo: «Dinastía y comunidad política. El momento de la patria», en Fernández Albaladejo, P. (ed): Los Borbones. Dinastía y memoria de nación en la España del siglo XVIII, Madrid, Casa de Velázquez-Marcial Pons, 2001, pp. 482-540.

108 GLESENER: op. cit. (nota 59).

109 [Federico De Prusia]: Anti-Machiavel, ou Essai de critique sur le prince de Machiavel, La Haya, 1740, pp. 77-78: "Tantos generales, tantos ministros y cancilleres pecheros! Europa está repleta, por su mayor felicidad porque esas plazas se dan al mérito".

${ }^{110}$ AGS, GM, Supl., leg. 603, f. 65: Mina a Ordeñada, Montpellier, 12 de marzo de 1747.

111 AGS, GM, Supl., leg. 603, f. 61: Mina a Ordeñana, Aix, 19 de febrero de 1747.
} 
En el reinado de Carlos III, los mismos acentos patrióticos se encontraban entre los miembros del mal llamado partido español o aragonés, tradicionalmente considerado como un foco de denuncia sistemática de la presencia de los extranjeros en los altos empleos de la monarquía ${ }^{12}$. Sin embargo, hay que diferenciar las campañas de propaganda llevadas contra algún ministro o algún alto militar de origen extranjero por motivos políticos, recurriendo a una fraseología de tipo xenófobo, de un movimiento general de rechazo a los extranjeros ${ }^{113}$. En efecto, esa nebulosa política reunió un abanico amplio de miembros de la aristocracia militar entre los cuales se encontraban las grandes familias de la nobleza flamenca. A principios de la década de 1770, entre los partidarios activos se contaba con casi todos los jefes de la guardia real, entre los cuales el conde de Priego, de la familia de Croÿ Havre, y el conde de Bournonvi$11 \mathrm{e}^{114}$. Esos dos hombres estaban íntimamente vinculados con las cabezas del partido español: los Bournonville eran parientes del conde de Aranda, uno de los líderes más destacados de la facción, y eran amigos del conde de Ricla, secretario de Guerra y primo de Aranda ${ }^{115}$. El conde de Priego, también íntimo del conde de Ricla, era el tío de Felipe Palafox Centurión, conde de Montijo, uno de los principales instigadores de la agitación nobiliaria bajo el reinado de Carlos III ${ }^{116}$. Esa proximidad no impidió tensiones y conflictos, pero permite relativizar el alcance de los ataques xenófobos. Por ejemplo, en 1781, el nombramiento del duque de Crillon al mando de la expedición de Menorca dio lugar a una de las campañas de xenofobia más virulentas en el seno de la élite militar ${ }^{117}$. Nativo de Aviñón, el duque de Crillon era el arquetipo del militar cortesano, pasado del servicio de Francia a España con 45 años con su antigüedad de teniente general ${ }^{118}$. A su llegada, fue recibido y recomendando por las cabezas de la aristocracia militar e integró ese mundo próximo al partido español. En 1780, cuando recibió la gran cruz de la Orden de Carlos III, fueron entre otros el duque de Arcos, el conde de Bournonville, capitanes de la guardia de corps, el conde de Ricla, y el duque de Osuna, coronel de las guardias españolas, quienes fueron llamados como testigos $^{119}$. A pesar de ello, al año siguiente, Crillon debió su nombramiento en la campaña de Menorca a la protección de Floridablanca y de sus aliados, lo que desató la ira de los que le habían rodeado hasta entonces ${ }^{120}$. Por lo tanto, fueron motivos políticos

112 Olaechea, Rafael: El conde de Aranda y el “partido aragonés”, Zaragoza, Universidad de Zaragoza, 1969; Hamnett, Brian R.: La política española en una época revolucionaria, 1790-1820, México, Fondo de Cultura Económica, 1985; Lluch, Ernest: Las Españas vencidas del siglo XVIII, Barcelona, Critica, 1999.

113 Sobre la interpretación de la violencia xenófoba, ver: Nirenberg, David: Violence et minorités au Moyen Age, París, Presses Universitaires de France, 2001.

114 Terrón Ponce, José Luis: Ejército y política en la España de Carlos III, Madrid, Ministerio de Defensa, 1997, pp. 13-15.

115 AGS, GM, leg. 2281; Moreno Meyerhoff, Pedro: «Linajes catalanes en el condado de Aranda: la casa de Rupit (siglos XIV-XVIII)», en Ferrer Benimeli, J.A. (dir.): El conde de Aranda y su tiempo, Zaragoza, Institución Fernando el Católico, 2000, vol. 2, pp. 99-134.

116 Morange, Claude: «El conde de Montijo. Reflexiones en torno al 'partido' aristocrático de 1794 a 1814 », Trienio, 4 (1984), pp. 33-61.

117 Sátira que se arrojó al público con motivo de haber elegido la Magestad del Señor D. Carlos III, el duque de Crillón por general en gefe del exército expedicionario destinado a la reconquista de Menorca, con preferencia a los dignos generales españoles [1783].

118 Crillon, Louis de Berton Balbes (duque de): Mémoires militaires, Paris, Imprimerie du Pont, 1791.

119 AHN, E, Carlos III, exp. 83.

120 Sobre el detalle del nombramiento: Terrón Ponce: op. cit. (nota 114), pp. 119-120. 
y no "nacionales" los que explican el brote xenófobo. El mismo conde de Aranda, el más perjudicado por el nombramiento de Crillon, si denunció la preferencia dada a un "extranjero" en vez de un "vasallo del rey y español", no pretendió discutir de forma global el derecho del rey de tener extranjeros en las filas de sus ejércitos. En un memorial bien conocido al príncipe de Asturias, escribió:

No piense Vuestra Altesa que yo sea antiextranjero, pues bien al contrario tengo la mejor idea de ellos, escogiendo los que lo merezcan (...) El príncipe se debe a sus vasallos, como estos a él. También se debe a los extranjeros mismos, que desde su primer servicio no han llevado otro uniforme. Y los hay, y ha habido muy dignos, y yo he servido a sus ordenes con infinitio aprecio de sus personas ${ }^{121}$.

El partido español reunió a una gran parte de la oligarquía militar que tenía en común el defender la supremacía de la jerarquía castrense sobre el control político de las Secretarías y de la administración ${ }^{122}$. Sin embargo, había tendencias muy diferentes, entre por ejemplo el conde de Aranda -que apelaba por la formación de un ejército nacional-, y los duques de Osuna -que sostenían los cuerpos privilegiados y una concepción estamental del ejército ${ }^{123}$. En ambos casos, la erosión de los derechos de la nación flamenca no procedió de la acción política del partido español, puesto que los jefes de los cuerpos flamencos formaban parte de esa facción, y que los privilegios de nación eran una pieza del patrimonio que la mayoría de la aristocracia militar pretendía defender frente a los ataques repetidos de la corona. Si hubo discrepancias sobre la forma de servir de los extranjeros, como nación o como individuos, el carácter fundamentalmente cosmopolita del ejército español no se cuestionó hasta finales del Antiguo Régimen. Aún en las Cortes de Cádiz, mientras había unanimidad sobre la exclusión de los cargos civiles de los extranjeros que no poseían carta de naturaleza, los diputados discreparon durante varios días sobre la cuestión de los cargos militares ${ }^{124}$. Por lo tanto, el ocaso de la nación flamenca en el ejército no se inscribió en un proceso de nacionalización, entendido como la marginalización del componente extranjero (que tardará aún mucho en concretarse), sino más bien en una reorganización de la economía de la gracia en el entorno del rey que erosionó los privilegios de la oligarquía militar. El ocaso de los derechos colectivos de la nación flamenca sólo fue un episodio de las múltiples

121 Archivo General de Palacio, Fernando VII, Caja 108, f. 89-90. Texto citado, en parte, en IgLESIAS, Carmen: «La nobleza ilustrada del XVIII español. El conde de Aranda», en Nobleza y Sociedad en la España moderna, Oviedo, Fundación Central Hispano-Nobel, 1996, pp. 249-288.

122 OlaecheA: op. cit. (nota 112), pp. 33-38; Lluch, Ernest: «La España vencida del siglo XVIII: Cameralismo, corona de Aragón y "Partido Aragonés" o "Militar"», Sistema: Revista de ciencias sociales, 124 (1995), pp. 13-41.

123 AndúJAR CASTILlo, Francisco: «El conde de Aranda y la capitanía general de Castilla la Nueva», en ARMiLlas Vicente, J.A. (ed.): Guerra y Milicia en la España del X conde de Aranda. Actas del IV Congreso de Historia Militar, Zaragoza, Gobierno de Aragón, 2002, pp. 55-71; OsunA, Pedro de Alcántara Téllez-Girón Pacheco (duque de): Sistema militar para España, que proponía el duque de Osuna, quando se trató de una organización nueva de nuestro ejército y se formó para ello la Junta de Generales en 1796 [1796] (Biblioteca Nacional de España, Manuscrito 10866).

${ }_{124}$ Diario de Sesiones de las Cortes Generales de España, 818 (7 de abril de 1813), p. 5005; 819 (8 de abril de 1813), pp. 5012-5014; 822 (11 de abril de 1813), pp. 5035-5038. 
afrentas que debió sufrir la oligarquía militar a finales del siglo XVIII y que la llevó a levantarse en Aranjuez en $1808^{125}$.

El ejército de naciones fue una pieza maestra de la herencia dejada por el felipismo, ese proyecto formado por Felipe V durante la guerra de Sucesión de refundar la nobleza española a partir de las familias más fieles a su causa. Con los cuerpos privilegiados, formaron parte de las estructuras creadas o renovadas para permitir a esa nueva élite cosmopolita asentarse y mantener una posición dominante. Eso permitió una rápida oligarquización de las familias felipistas, creando con el paso del tiempo, como lo ilustra el caso de los flamencos, distorsiones entre una posición social elevada y una influencia política decaída. Por lo tanto, de Fernando VI a Carlos IV, los descendientes de Felipe V tuvieron cada uno a su manera que manejar con esa aristocracia militar, vacilando entre reformar las estructuras o eliminar a las familias que las controlaban. Los cuerpos de nación fueron el núcleo más reacio al cambio, pero terminaron por decaer frente al auge conjunto del control administrativo y del clientelismo real. En todo caso, los conflictos en torno al ejército de naciones se deben entender como una versión española del gran antagonismo del siglo XVIII entre las concepciones estamentales y meritocráticas del ejército. A pesar de los discursos, las críticas a las naciones no cuestionaron fundamentalmente el carácter cosmopolita del ejército y el derecho del rey a premiar los extranjeros con empleos militares. Fueron las formas de servir de esos militares que planteó el reformismo ilustrado, criticando el corporativismo basado en los privilegios de naciones, $\mathrm{y}$ favoreciendo las formas individuales de servicio fundadas en reglas universales.

Por lo tanto, el auge y el ocaso de la nación flamenca en el ejército borbónico no fue una historia aparte respecto a una historia general de las élites que habría ido por una senda separada y cuyo eje central estaría en la nobleza autóctona. Al contrario, la presencia militar flamenca, como grupo privilegiado en el seno del ejército, se explica, tanto en su origen como en su disolución, por procesos históricos globales que afectaron al conjunto de las élites de la monarquía. Así que, por formar parte de esas élites, el estudio de la presencia extranjera en el Estado borbónico debe inscribirse plenamente en la historiografía de la nobleza española.

125 GLESENER: op. cit. (nota 88), pp. 336-346. 